\title{
Yeşil Ürün Satın Alma Davranışı, Kişilerarası Etkilenme Eğilimi ve Sosyal Etki Arasındaki İlişki: Üniversite Öğrencileri Üzerine Bir Araştırma
}

\section{The Relationship Between Green Product Buying Behaviours, Susceptibility to Interpersonal Influence and Social Impact: A Research on University Students}

Öğr. Gör. Müesser KORKMAZ

Çanakkale Onsekiz Mart Üniversitesi

Gökçeada Uygulamalı Bilimler YO

E-posta:muesser.cesur89@gmail.com

Orcid Id:0000-0002-9538-6254
Doç. Dr. Lütfi ATAY

Çanakkale Onsekiz Mart Üniversitesi

Turizm Fakültesi

E-posta: lutfiatay@yahoo.com

Orcid Id:0000-0003-2598-6227

Yrd. Doç. Dr. H. Mehmet YILDIRIM

Çanakkale Onsekiz Mart Üniversitesi

Turizm Fakültesi

E-posta:hadjimehmet@gmail.com

Orcid Id:0000-0003-0718-7296

Öz

$\mathrm{Bu}$ çalışmada lisans düzeyindeki öğrencilerin yeşil satın alma davranışları ile kişilerarası etkilenme eğilimi ve sosyal etki faktörleri arasındaki ilişkinin belirlenmesi amaçlanmıştır. Bu amaçla Çanakkale Onsekiz Mart Üniversitesi ve Balıkesir Üniversitesi Çevre Mühendisliği Bölümlerinde lisans eğitimi alan toplam 264 öğrenciye anket uygulanmıştır. Araştırmadan elde edilen verilerin analizinde faktör analizi, korelasyon analizi ve basit doğrusal regresyon analizi kullanılmıştır. Araştırma sonucunda kişilerarası etkilenme eğilimi ve sosyal etki ile öğrencilerin yeşil ürün satın alma davranışları arasında pozitif yönlü ilişkinin olduğu belirlenmiştir. Araştırmada ayrıca öğrencilerin yeşil ürün satın alma davranışlarının eğitim görülen sınıf düzeyine göre de anlamlı farklılıklar gösterdiği tespit edilmiştir.

Anahtar Kelimeler: Yeşil ürün, Sosyal etki, Yeşil pazarlama, Yeşil satın alma davranışı

\begin{abstract}
In this study, it was aimed to determine the relationship between bachelor level students' green product buying behaviors with susceptibility to interpersonal influence and social impact. For this purpose, survey was applied to total of 264 students studying at Department of Environmental Engineering of Canakkale Onsekiz Mart University and Balıkesir University. Factor analysis, correlation analysis and simple linear regression analysis were used in the analysis of the obtained data. Following the research, it was determined that there is a positive relationship between susceptibility to interpersonal influence and social impact with students' green product buying behaviors. In the research, it was also determined that students' buying behavior of green products showed significant differences according to the class level of education.
\end{abstract}

Key Words: Green product, Social impact, Green marketing, Green buying behavior 


\section{Giriş}

Yeşil pazarlama 1980 'lerin sonu ve 1990 'ların başında ortaya çıkmasına rağmen, bu tarihlerden çok daha önceleri tartışılmaya başlanmıştır. (Polonsky, 1994; Peattie ve Crane, 2005; Ayyıldız ve Genç, 2008; Türk ve Gök, 2010; Kuduz, 2011; Kükrer, 2012). Paço, Raposo ve Filho $(2009,18)$ "yeşil pazarlamanın karlı ve sürdürülebilir bir şekilde tüketicilerin ve toplumun ihtiyaçlarının belirlenmesi ve tatmin edilmesi için uygulanan bütüncül bir yönetim yaklaşımı" olduğunu ifade etmektedir. Çevresel pazarlama, ekolojik pazarlama ve sürdürülebilir pazarlama olarak da ifade edilen yeşil pazarlama genellikle işletmelerin çevreye zarar vermeyecek ürünlerin tasarlanması, tutundurulması, fiyatlandıııması ve dağıtımasına yönelik çabalar olarak tanımlanmaktadır (Jain ve Kaur, 2004: 188).

Günümüzde çevresel problemlerdeki artıştan dolayı tüketicilerin satın alma davranışlarını yeşil satın alma davranışına dönüştürme eğilimi içerisinde oldukları gözlenmektedir. Mostafa (2007: 220), "yeşil/çevre dostu satın alma davranışını çevrenin korunması, kirliliğin minimize edilmesi, yenilenebilir olmayan kaynakların kullanımına ilişkin sorumluluk geliştirilmesi ve diğer canlı türlerinin korunmasına yönelik geliştirilen tüketici davranışı" olarak tanımlamaktadır. Park ve Sohn (2012) çevre dostu/yeşil tüketimde tüketicilerin tutum ve davranışları arasında önemli farklılıklar bulunduğunu ve bu farklılıkların tüketicilerin çevre dostu davranış özelliklerinden kaynaklandığını belirtmektedir. Yapılan yazın taraması sonucunda tüketicilerin yeşil ürün satın alma tutum ve davranışları arasındaki farklılıklara ilişkin çeşitli görüşlerin varlığından söz etmek mümkündür. Bazı araştırmacılar yeşil tüketicilerin satın alma davranışlarına etki eden faktörleri; çevresel değerler ve kaygılar ile demografik değişkenler ve psikolojik faktörler olarak ifade ediyorken (Straughan ve Roberts, 1999), bazı araştırmacılar ise yeşil tüketim davranışının sosyal (toplumsal) faktörler tarafından büyük ölçüde etkilenme eğiliminde olduğunu ileri sürmektedir (Khare ve diğ., 2013).

Bu çalışmanın amacı yüksek çevre bilincine sahip olduğu düşünülen çevre mühendisliği bölümünde lisans eğitimi gören üniversite öğrencilerinin yeşil satın alma davranışları üzerindeki sosyal etkilerin belirlenmesidir. Bu bağlamda kişilerarası etkilenme eğilimi ve sosyal etki faktörlerinin lisans düzeyindeki öğrencilerin yeşil satın alma davranışları üzerindeki etkileri araştırılmıştır. Sosyal etkiler tüketicilerin yeşil satın alma davranışlarında toplumsal normların ve değerlerin etkisini incelerken, kişilerarası etkilenme eğilimi tüketicilerin yeşil satın alma davranışındaki normatif (ahlak ve değer yargılarına dayanan) ve informatif değerlerin etkisini incelemektedir.

\section{Literatür Taraması}

Dünyada yaşanan sosyal, ekonomik ve siyasi gelişmeler ile çevre sorunlarının neden olduğu kaygılara paralel olarak, çevre kavramı ve çevreye yönelik algı önemli ölçüde değişmiştir (Atay ve Dilek, 2013: 203). Bu değişim ürünlerden üretim süreçlerinden ve çevresel felaketlerden kaynaklanan çevresel sorunlar nedeniyle son 30 yıl içerisinde çevreciliğin önemini arttırmıştır (Kalafatis ve diğ., 1999). Tüketiciler için çevrecilik 1960'lı yıllarda "farkına varma/bilinçlenme periyodu olarak ifade edilirken, 1970'ı yıllarda "harekete geçme", 1980'lı yıllarda "sorumlu hissetme/sorumluluk üstlenme", 1990 'lı yıllarda ise "pazar gücü olma" dönemleri olarak ifade edilmektedir (Easterling ve diğ., 1996; Kalafatis ve diğ., 1999; Arabacıoğlu ve Tatıdil, 2009; Ay ve Ecevit, 2010; Kuduz, 2011). Çevreye yönelik artan ilginin, tüketiciler tarafından doğal kaynakların sınırlı olduğunun farkına varılması ve enerji ile yenilenebilir olmayan kaynakların aşırı kullanımından kaynaklanan sorunların belirgin bir şekilde görünür olmasından kaynaklanmaktadır (Kükrer, 2012: 4507; Untaru ve diğ., 2014). Dolayısıyla tüketiciler 
1960'ı yılların sonları 1970'li yılların başlarında çevresel konularla daha fazla ilgili hale gelmeye başlamışlardır (Easterling ve diğ., 1996: 25).

Çevresel bozulma günümüz dünyasının yüzleşmekte olduğu en ciddi problemlerden biri olarak kabul edilmekte ve çevre ile ilgili konulara ilişkin mevcut tüketici bilinci her geçen gün artmaktadır (Dagher ve Itani, 2014: 188). Buna ek olarak çevresel konuların medyada daha fazla yer alması, çevresel problemlere ilişkin farkındalık düzeyinin artması, baskı gruplarının faaliyetlerinin artması ve bunların bir toplamı olarak yasal düzenlemelerin getirdiği uygulamalarla tüketici bilinç düzeyinde dikkate değer ölçüde bir gelişme meydana gelmiştir (Kalafatis ve diğ., 1999: 441). Tüketicilerin çevreye yönelik yüksek hassasiyet geliştirdikleri ve işletmelerden de doğayı daha iyi koruyacak uygulamalar geliştirmelerini bekledikleri gözlemlenmektedir. Bu bağlamda, şu andaki mevcut tüketim hızıyla ileride mevcut yaşam kalitesinin devam ettirilemeyeceğine ilişkin artan kaygının yeşil tüketici sayısını artırdığı söylenebilir. Alan yazınına bakıldığında, kendilerini ve çevrelerini, satın alma güçlerini kullanarak korumayı hedefleyen kişilerin yeşil tüketici olarak tanımlandığı bilinmektedir (Ayyıldız ve Genç, 2008: 506). Kuduz (2011: 209) yeşil tüketiciyi, "satın alma ve tüketim faaliyetlerinin çevreye etkilerine dikkat eden, bu doğrultudaki inançlarına göre davranan, bu amaçlar doğrultusunda gayret gösteren, rasyonel karar alıcılar" olarak tanımlanmaktadır.

Yeşil tüketiciler yeşil ürün satın alma, geri dönüşüm ve enerji tasarrufu gibi farklı yöntemlerle doğal çevreyi korumaya yönelik çeşitli tüketim davranışları sergilemektedirler (Paço ve diğ. 2013). Bu bağlamda yeşil ürün ve yeşil paketleme tasarımı, yeşil reklam ve yeşil pazarlama stratejileri gibi pazarlama uygulamalarındaki çevresel faaliyetler yeşil tüketim davranışı ile ilişkilendirilmektedir. Bu noktada yeşil satın alma davranışı doğal kaynakları ve doğal çevreyi korumayı ilke edinen etik bir tüketici davranışı olarak kabul edilmektedir. Atık yönetimi ve çevre dostu ürünleri satın alma gibi tüketici davranışları böylelikle giderek tüketicilerin günlük yaşantısının bir parçası haline gelmektedir (Autio ve Heinonen, 2004: 141). Bir başka deyişle tüketicilerin çevresel konulara ilişkin çeşitli düzeylerdeki hassasiyetleri satın alma davranışlarını etkilemektedir (Çabuk ve Nakıboğlu, 2003: 43). Yeşil tüketici davranışı çok sayıda faktörden etkilenme eğilimi göstermektedir (Jansson ve diğ., 2010). Yeşil tüketici davranışına etki eden bu faktörler genel olarak "demografik değişkenler, psikolojik faktörler, çevresel ve sosyal değerler" olmak üzere üç temel başlık altında incelenmektedir (Gilg ve diğ., 2005: 482).

İlgili alan yazınında yeşil satın alma davranışını etkileyen faktörlerin belirlenmesine yönelik çeşitli çalışmalar yer almaktadır. Straughan ve Roberts (1999), Amerika'da 235 üniversite öğrencisi üzerinde gerçekleştirdikleri çalışmada, demografik değişkenlerin yeşil tüketici davranışını tanımlamada önemli bir yere sahip olduğu sonucuna ulaşmıştır. Çalışmada genç insanların daha yüksek çevresel duyarlılığa sahip olduğu, erkeklere kıyasla kadınların daha duyarlı tüketim davranışı sergiledikleri, eğitim seviyesi ile çevresel tutum ve davranışlar arasında pozitif yönlü bir ilişki olduğu tespit edilmiştir. Xiao ve McCright (2015) çevre koruma ve çevresel sorunlara duyarlı tüketim davranışını demografik faktörler kapsamında incelemiştir. Çalışmada çevre koruma ve çevresel sorunlara duyarlııı bağlamında kadınların erkeklere kıyasla daha çevreci davranışlar sergiledikleri ve çevresel sorunlara daha duyarlı oldukları sonucuna ulaşılmıştır.

Ay ve Ecevit (2010), çevre bilinçli tüketici davranışı ile demografik ve psikografik özellikler arasındaki ilişkiyi belirlemek amacıyla 460 üniversite öğrencisi üzerinde bir araştırma gerçekleştirmişlerdir. Araştırma sonucunda yeşil tüketici davranışını 
belirlemede algılanan tüketici etkinliği, çevresel kaygı ile sosyal ve politik konulara duyarlılıktan oluşan psikografik değişkenlerin demografik değişkenlerden daha etkili olduğu belirlenmiştir. Karaca (2013) ise, bireylerin demografik özellikleri ile çevre bilinci ve çevreye duyarlı ürünleri kullanma eğilimleri arasındaki ilişkiyi belirlemek amacıyla Sivas ilinde 362 örneklemle yaptığı araştırmada, yaş, cinsiyet, medeni durum, eğitim düzeyi meslekten oluşan demografik özellikler ile çevre dostu ürün satın alma ve çevre dostu ürün bilinci arasında anlamlı farklılıklar bulunduğu sonucuna ulaşmıştır.

Dagher ve Itani (2014), yeşil tüketici davranışına katkıda bulunan faktörlerin belirlenmesi amacıyla 135 Lübnanlı tüketici üzerinde bir araştırma gerçekleştirmiştir. Çevresel sorunların algılanan ciddiyeti, algılanan çevresel sorumluluk, çevre dostu davranışın algılanan etkinliği ve çevre koruma davranışına yönelik öz-eleştiri değişkenleri test edilmiştir. Araştırma sonucunda yeşil tüketici davranışı ile çevresel sorunların algılanan ciddiyeti, çevresel sorumluluk algısı ve çevreci davranışa yönelik öz-eleştiri değişkenleri arasında pozitif yönlü bir ilişki olduğu, dolayısıyla bu üç faktörün yeşil tüketici davranışını geliştiren faktörler olduğu tespit edilmiştir. Araştırmada yeşil tüketici davranışının gelişmesine katkıda bulunan temel faktörün ise çevresel problemlerin algılanan ciddiyeti olduğu tespit edilmiştir.

Cheah ve Phau (2011), tüketicilerin çevre dostu ürünleri satın alma isteğini etkileyen faktörleri belirlemek amacıyla Avustralya'da işletme eğitimi alan 600 üniversite öğrencisi üzerinde gerçekleştirdikleri araştırmada; çevresel bilinç, kişilerarası etki, bireycilik ve toplumculuktan oluşan değer yönelimi ile öğrencilerin yeşil ürün satın alma isteği arasında güçlü bir ilişki olduğunu tespit etmişlerdir. Araştırmada çevreye duyarlı öğrencilerin çevre dostu ürünleri satın alma eğilimlerinin diğer öğrencilere kıyasla daha yüksek olduğu ve algılanan ürün gerekliliğinin çevre dostu ürünlere yönelik tutumlar ile bu ürünleri satın alma istekliliği arasındaki ilişkiyi yönettiği sonucuna ulaşılmıştır.

Minton ve Rose (1997), Southern Üniversitesi'nde çevresel endişe ve sosyal normların yeşil tüketici davranışı üzerindeki etkisini belirlemek amacıyla 114 tüketici üzerinde bir araştırma gerçekleştirmişler. Araştırmada çevresel kaygıların, kişisel ve sosyal normların tüketicilerin davranışları ve davranışsal niyetleri üzerinde önemli ölçüde etki sahibi olduğu belirlenmiştir. Araştırma sonucunda çevresel tutumların davranışsal niyetler üzerinde, kişisel normların ise tüketici davranışları üzerinde etki sahibi olduğu tespit edilmiştir. Wahid ve diğerleri (2011), Penang'ta çevre ile ilgili faaliyetlere katılan "yeşil gönüllülerin" yeşil satın alma davranışlarını etkileyen faktörlerin belirlenmesi amacıyla bir araştırma gerçekleştirmişlerdir. Araştırmanın değişkenlerini sosyal etkiler, öz-farkındalık, ekolojik etki, çevresel etiket, çevresel bilgi, çevresel tutum ve çevresel kaygı oluşturmaktadır. Araştırmada önem sırasına göre sosyal etkilerin, çevresel kaygının, yeşil ürün bilgisinin, çevre bilgisinin ve çevresel etiketin yeşil tüketim davranışını etkilediği tespit edilmiştir.

Sharma (2014), Sunshine Coast tabanlı üç şirketin tüketicilerinin yeşil satın almaya yönelik tutumlarını, yeşil tüketim davranışlarını ve sosyal etkilere ve yeşil uygulamaları teşvik etmeye ilişkin hükümet politikalarına yönelik algılarını belirlemek ve bunların birbirleriyle ilişkisini incelemek amacıyla bir araştırma gerçekleştirmiştir. Araştırmada tüketicilerin yeşil ürünlere yönelik tutumlarının olumlu yönde olduğu ve tüketicilerin yeşil ürün satın alma tutumları ile geri dönüşüm, yeniden kullanım, atık kompostlama ve çevreyle ilgili diğer faaliyetlerde bulunmaları arasında pozitif yönlü ilişki olduğu tespit edilmiştir. Buna ek olarak araştırmada sosyal etkiler ile tüketicilerin çevresel alışkanlıkları ve çevre koruma davranışları arasında pozitif yönlü ilişki olduğu 
tespit edilirken, tüketicilerin yeşil ürün satın almaya yönelik tutumları ile hükümet kararları arasında negatif yönlü ilişki olduğu tespit edilmiştir.

Park ve Sohn (2012), toplumsal normların (buyruksal ve betimsel) çevre dostu tüketim davranışı üzerindeki rolünü incelemek amacıyla 267 yetişkin üzerinde bir araştırma gerçekleştirmiştir. Araştırma sonucunda sosyal normların, çevresel normların ve kendini gözlemleme (öz-izleme) davranışının çevre dostu tüketim davranışı üzerinde etki sahibi olduğu tespit edilmiştir. Araştırmada yüksek düzeyde kendini gözlemleyen bireylere ait yeşil tüketim davranışının buyruksal normlar tarafından, düşük düzeyde kendini gözlemleyen bireylere ait yeşil tüketim davranışının ise betimsel normlar tarafından etkilendiği sonucuna ulaşılmıştır. Khare ve diğ. (2013) kolektif öz-saygının, kişilerarası etkilenme eğiliminin (normatif-informatif) değerlerin ve sosyal etkinin yeşil satın alma davranışı üzerindeki etkisini belirlemek amacıyla Hindistan'ın altı ayrı şehrinde (New Delhi, Bangalore, Udaipur, Chennai, Chandigarh, ve Kolkata), 501 Hint tüketici üzerinde bir araştırma gerçekleştirmiştir. Araştırmada normatif ve informatif değerlerin, sosyal etkinin ve grup saygınlığının tüketicilerin yeşil satın alma davranışı üzerinde önemli ölçüde etkili olduğu sonucuna ulaşılmıştır.

\section{Araştırmanın Yöntemi}

İlgili alan yazınında tüketicilerin yeşil ürün satın alma davranışı ile demografik, psikolojik, çevresel ve sosyal faktörler arasındaki ilişkinin incelenmesine yönelik çeşitli çalışmaların olduğu görülmektedir. Ancak alan yazın taramasında yüksek çevre bilincine sahip olduğu ön görülen çevre mühendisliği bölümü öğrencilerinin yeşil satın alma davranışlarına etki eden faktörlerin belirlenmesine ilişkin herhangi bir çalışmaya rastlanılmamıştır. Oysa çevre mühendisliği bölümü öğrencilerinin aldıkları eğitim çevresel duyarlılıklarının geliştirilmesi açısından oldukça önemlidir. Çünkü bu bölüm doğal kaynakların kullanımı ve insan sağlığına uygun koşulların yaratılması ile ilgili eğitimin verildiği bir mühendislik bölümüdür. Bölümün başlıca çalışma alanları ise; su ve atık arıtma, hava kirliliği kontrolü, katı atık bertaraftı, toprak kirliliği ve çevresel etkilerin değerlendirilmesi gibi çeşitli çevre koruma alanlarıdır.

Bu kapsamda çevresel açıdan gerek teorik gerekse pratik bilgiye sahip olduğu düşünülen çevre mühendisliği öğrencilerinin çevre dostu ürünleri satın almasında etkili olan faktörlerin belirlenmesi öğrencilerin yeşil satın alma davranışlarının etkin bir biçimde anlaşılması açısından önemlidir. Bu kapsamda sosyal yaşam ile daha yakın bir ilişki içinde oldukları bilinen üniversite öğrencilerinin yeşil satın alma davranışlarının kişilerarası etkilenme eğilimi ve sosyal faktörler tarafından etkilenip etkilenmediği bu çalışmanın temel araştırma sorusunu oluşturmaktadır. Dolayısıyla çalışmada çevre mühendisliği bölümünde lisans eğitimi gören öğrencilerin yeşil satın alma davranışları ile kişilerarası etkilenme eğilimi ve sosyal etki arasında bir ilişki olup olmadığı ve eğer bir ilişki söz konusuysa belirtilen faktörlerin öğrencilerin yeşil satın alma davranışını ne yönde ve ne ölçüde etkilediği belirlenmeye çalışılmaktadır.

Çevre eğitimi alan üniversite öğrencilerinin yeşil satın alma davranışlarına etki eden sosyal faktörlerin belirlenmesi, gerek öğrencilerin yeşil satın alma davranışlarının anlaşılmasında gerekse işletmelerin sosyal faktörler bağlamında pazarlama faaliyetlerindeki değişimlerine rehberlik etmesi bakımından oldukça önemlidir. Üniversite eğitimi sonrası etkin bir tüketici kitlesi haline gelmeleri beklenen öğrencilerin yeşil satın alma davranışlarına etki eden sosyal faktörlerin belirlenmesiyle gerek tüketim tercihleri bakımından öğrencilerin, gerekse arz yaratma faaliyetleri bakımından işletmelerin, sürdürülebilir bir hayatın oluşumuna katkı sağlaması düşünülmektedir. Bu doğrultuda araştırmanın hipotezleri alan yazınında yeşil ürün satın alma davranışını 
kişilerarası etki ve sosyal etki bağlamında inceleyen çalışmalardaki hipotezler temel alınarak oluşturulmuştur.

Cheah ve Phau (2011), tarafından yapılan çalışmada kişilerarası etkinin tüketicilerin çevre dostu tutumlarına yönelik yüksek kişilerarası etkinin tüketicilerin çevre dostu tutumlarını pozitif yönde etkileyeceği hipotezi test edilmiştir. Benzer şekilde Sharma (2014)'nın çalışmasında sosyal etkinin tüketicilerin yeşil uygulamalarını etkileyip etkilemediğine ilişkin araştırma sorusu geliştirilmiştir. Khare ve diğ. (2013) tarafından yapılan çalışmada da kişilerarası etki ve sosyal etkinin tüketicilerin yeşil ürün satın alma davranışını etkilediğine ilişkin hipotezler test edilmiştir. Bu kapsamda alan yazınında yer alan çalışmalardan hareketle bu çalışmanın hipotezleri şu şeklide oluşturulmuştur.

H1: Kişilerarası etkilenme eğilimi ile yeşil ürün satın alma davranışı arasında pozitif yönlü bir ilişki vardır.

H2: Sosyal etki ile yeşil ürün satın alma davranışı arasında pozitif yönlü bir ilişki vardır.

Çalışmanın verileri birincil kaynaktan veri toplamada en çok tercih edilen tekniklerden biri olan anket tekniği aracılığıyla toplanmıştır. Bu kapsamda çalışmada Khare ve diğ. (2013) tarafından gerçekleştirilen çalışmada kullanılan kişilerarası etkilenme eğilimi ölçeği ve çevresel tutum ölçeğinden yararlanılmıştır. Çalışmada kullanılan anket formu 2 bölümden oluşmaktadır. Birinci bölümde 10 sorudan oluşan kişilerarası etkilenme eğilimi ölçeği, ikinci bölümde ise 11 sorudan oluşan çevresel tutum ölçeği bulunmaktadır. Kişilerarası etkilenme eğilimi ölçeği öğrencilerin yeşil ürün satın alma davranışının arkadaşları, yakın çevresi veya diğer insanlar tarafından etkilenip etkilenmediğini ölçerken, çevresel tutum ölçeği öğrencilerin arkadaşları ile çevresel konulardaki etkileşimlerini (çevresel konular üzerinde tartışmak, yeşil ürünlere ilişkin bilgi paylaşımında bulunmak vs.) ve yeşil ürün tercih eğilimlerini (az kimyasal bileşen içeren, dönüştürülebilir olarak paketlenen, güvenli olarak etiketlenen vs.) ölçmektedir. Her iki ölçek de 5 'li likert tipi ölçek olup, öğrencilerden ilgili soruları kesinlikle katılmıyorum ile kesinlikle katılıyorum aralığındaki bir derecelendirme ile yanıtlamaları istenmiştir. Anket formunun üçüncü bölümünde ise öğrencilerin cinsiyetini, sınıfını, ailesinin eğitim ve gelir düzeyini belirlemeye yönelik oluşturan demografik sorular yer almaktadır.

Çalışmanın evrenini üniversitelerin Çevre Mühendisliği Bölümünde lisans eğitimi alan öğrencileri oluşturmaktadır. Araştırmada örnekleme yöntemi olarak olasılığa dayalı olmayan örnekleme yöntemlerinden kolayda örnekleme kullanılmıştır. Bu bağlamda araştırmanın örneklemi Çanakkale Onsekiz Mart Üniversitesi ve Balıkesir Üniversitesi Çevre Mühendisliği Bölümünde lisans düzeyinde eğitim göre toplam 264 üniversite öğrencisinden oluşmaktadır.

\section{Bulgular}

Çanakkale Onsekiz Mart Üniversitesi ve Balıkesir Üniversitesi Çevre Mühendisliği Bölümü öğrencilerinin demografik özellikleri Tablo 1'deki gibidir. Tablo 1'e göre araştırmaya katılanların \%64,4'ü erkek, \%35,6'sı kız öğrencilerden oluşmaktadır. Ankete katılan öğrencilerin \%33'ü son sınıf öğrencisi olup, öğrencilerin annelerinin eğitim düzeyinin çoğunluğunun, babalarının eğitim düzeylerinin ise \%36'sının ilköğretim düzeyinde olduğu görülmektedir. Bu durum Türkiye'deki kadın istatistikleri ile de tutarlıık göstermektedir. Öyle ki, Türkiye İstatistik Kurumu (TUIK) tarafından 
yayımlanan "Kadın 2015 Raporunda" okuma yazma bilmeyen kadın nüfus oranının erkeklerden 5 kat fazla olduğu görülmektedir. Bu kapsamda rapora göre, Türkiye'de okuma yazma bilmeyen toplam nüfus oranı \%5,6 iken bu oran erkeklerde \%1,8 kadınlarda ise \%9,2'dir. Ayrıca rapora göre lise ve dengi okullar ile yüksekokul ve fakülte mezunu olan kadınların toplam nüfus içindeki oranı erkeklere kıyasla daha düşüktür (www.tuik.gov.tr). Öğrencilerin aylık ortalama hane gelirine bakıldığında, \%60'lık bir kesimin 1000-3000 TL arasında bir gelire sahip olduğu görülmektedir. Türkiye İşçi Sendikaları Konfederasyonu (TÜRK-IŞ) tarafından yapılan araştırmanın sonuçlarından hareketle dört kişilik bir ailenin yoksulluk sınırının Mart 2017 itibariyle 4.823,31 (www.turkis.org.tr) olduğu göz önünde bulundurulduğunda öğrencilerin çoğunun dar gelirli bir ailede yaşadığını söylemek mümkündür.

Tablo 1: Araştırmaya Katılan Öğrencilerin Demografik Özellikleri

\begin{tabular}{|c|c|c|c|c|c|}
\hline Cinsiyet & $\mathbf{N}$ & $\%$ & Baba Eğitim Durumu & $\mathbf{N}$ & $\%$ \\
\hline Kadın & 94 & 35,6 & İlköğretim & 95 & 36,0 \\
\hline Erkek & 170 & 64,4 & Ortaöğretim & 92 & 34,8 \\
\hline Toplam & 264 & 100 & Ön lisans & 11 & 4,2 \\
\hline Sınıf Dağılımları & $\mathbf{N}$ & $\%$ & Lisans & 61 & 20,1 \\
\hline Birinci Sınıf & 76 & 28,8 & Lisansüstü & 5 & 1,9 \\
\hline ikinci Sınıf & 72 & 27,3 & Toplam & 264 & 100 \\
\hline Üçüncü Sınıf & 29 & 11,0 & Aylık Ortalama Hane Geliri & $\mathbf{N}$ & $\%$ \\
\hline Dördüncü Sınıf & 87 & 33 & 1000 TL'den az & 22 & 8,3 \\
\hline Toplam & 264 & 100 & $1001-2000 \mathrm{TL}$ & 82 & 31,1 \\
\hline Anne Eğitim Durumu & $\mathbf{N}$ & $\%$ & $2001-3000 \mathrm{TL}$ & 77 & 29,2 \\
\hline İlköğretim & 145 & 54,9 & 3000 TL ve üzeri & 83 & 31,4 \\
\hline Ortaöğretim & 73 & 27,7 & Toplam & 264 & 100 \\
\hline Ön lisans & 6 & 2,3 & & & \\
\hline Lisans & 36 & 13,6 & & & \\
\hline Lisansüstü & 4 & 1,5 & & & \\
\hline Toplam & 264 & 100 & & & \\
\hline
\end{tabular}

Öğrencilerin kişilerarası etkilenme eğilimlerinin ölçülmesine yönelik ifadelerin faktör analizi sonuçları Tablo 2'de gösterilmektedir. Kişilerarası etkilenme eğilimi ölçeği toplam 10 maddeden oluşmakla birlikte uygulanan analiz neticesinde faktör yükü 0,50'nin altında olan bir ifadenin ölçekten çıkarılması uygun görülmüş ve ölçekten danışma, beğenilme ve onaylanma olmak üzere toplam üç faktör elde edilmiştir. Bu faktörlerden ilki olan danışma faktörü toplam üç ifadeden oluşmakla birlikte toplam varyansın \%24,82'sini açıklamaktadır. Faktörü oluşturan değişkenler incelendiğinde major değişkenin "Bir ürün sınıfından mevcut en iyi alternatifi seçmek için çoğunlukla diğer insanlara danışırım" (,864) olduğu görülmektedir. Faktöre ilişkin ortalama değere $(2,14)$ bakıldığında, kişilerarası etkilenme değişkenlerinden danışma faktörünün öğrencilerin kişilerarası etkilenme eğilimleri üzerinde kısmen etkili olduğu görülmektedir.

"Beğenilme" olarak adlandırılan ikinci faktör üç ifadeden oluşmakta ve toplam varyansın \%22,13'ünü açıklamaktadır. Bu faktördeki major değişken “İnsanların kullandığım ürünü görebilecekleri durumlarda çoğunlukla onların benden beklediği ürünleri satın alırım" ifadesidir (,796). Faktöre ilişkin ortalama değere $(, 80)$ bakıldığında beğenilme faktörünün öğrencilerin kişilerarası etkilenme eğilimleri üzerinde son derece düşük bir etkiye sahip olduğu görülmektedir. Ölçekte ulaşılan üçüncü ve son faktör ise onaylanma olarak adlandırımıştır. Bu faktör üç ifadeden oluşmakta ve toplam varyansın \%15,33'ünü açıklamaktadır. Faktörü oluşturan major değişkenin "En son moda ürünleri nadiren arkadaşlarımın onayını almadan satın alırım" $(, 748)$ ifadesi 
olduğu görülmektedir. Faktöre ilişkin ortalama değere bakıldığında $(1,98)$, "Onaylanma" faktörünün öğrencilerin kişilerarası etkilenme eğilimleri üzerinde kısmen etkili olduğu görülmektedir.

\section{Tablo 2: Öğrencilerin Kişilerarası Etkilenme Eğilimlerinin Ölçülmesine Yönelik İfadelerin Faktör Analizi Sonuçları}

\begin{tabular}{|c|c|c|c|}
\hline 1.FAKTÖR Danışma & Eş Kök. & Yük & \\
\hline $\begin{array}{l}\text { Bir ürün sınıfından mevcut en iyi alternatifi seçmek } \\
\text { için çoğunlukla diğer insanlara danışırım. }\end{array}$ & ,758 & ,864 & \multirow{3}{*}{$\begin{array}{l}\text { Öz Değer: } 2,23 \\
\text { Varyans: } \% 24,82 \\
\text { Ortalama: } 2,14\end{array}$} \\
\hline $\begin{array}{l}\text { Eğer bir ürüne ilişkin az sayıda bilgim varsa, } \\
\text { çoğunlukla ürün hakkında arkadaşlarıma danışırım. }\end{array}$ & ,703 & 838, & \\
\hline $\begin{array}{l}\text { Ürün satın almadan önce çoğunlukla yakın } \\
\text { çevremden bilgi toplarım. }\end{array}$ & 642 & ,790 & \\
\hline \multicolumn{4}{|l|}{ 2. FAKTÖR Beğenilme } \\
\hline 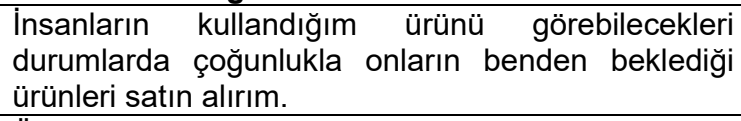 & ,645, & ,796 & \multirow{3}{*}{$\begin{array}{l}\text { Öz Değer: } 1,99 \\
\text { Varyans: } \% 22,13 \\
\text { Ortalama: }, 80\end{array}$} \\
\hline $\begin{array}{l}\text { Ürün satın alırken genellikle diğer insanların } \\
\text { beğendiğini düşündüğüm ürünleri satın alırım. }\end{array}$ & ,634 & ,775 & \\
\hline $\begin{array}{l}\text { Çoğunlukla diğer insanların satın aldığı ürünlere } \\
\text { benzer ürünler satın alııım. }\end{array}$ &, 586 & ,724 & \\
\hline \multicolumn{4}{|l|}{ 3. FAKTÖR Onaylanma } \\
\hline $\begin{array}{l}\text { En son moda ürünleri nadiren arkadaşlarımın } \\
\text { onayını almadan satın alırım. }\end{array}$ & ,569 & ,748 & \multirow{3}{*}{$\begin{array}{l}\text { Öz Değer: } 1,38 \\
\text { Varyans: } 15,33 \\
\text { Ortalama: } 1,98\end{array}$} \\
\hline $\begin{array}{l}\text { Kullandığım ürünlerin } \begin{array}{c}\text { diğer insanlar } \\
\text { yarattığı izzerinde } \\
\text { izlenimin } \\
\text { iyi olduğlanınu }\end{array} \\
\text { bilmekten }\end{array}$ & ,495 & ,649 & \\
\hline $\begin{array}{l}\text { Satın aldığım ürünleri diğer insanların beğenmesi } \\
\text { benim için önemlidir. }\end{array}$ & ,573 &, 569 & \\
\hline
\end{tabular}

Varimax rotasyonlu temel bileşenler analizi. Açıklanan toplam varyans \%62,28

Kaiser-Meyer-Olkin örneklem yeterliliği: \%70,5 Barlett küresellik testi: X2: 517,538 s.d.: 36 p<0,001

Güvenilirlik: ,682 F-değeri 72,292 p-değeri,000

Öğrencilerin çevresel tutumlarına ilişkin ifadelerin faktör analiz sonuçları Tablo 3'teki gibidir. Toplam 11 maddeden oluşan çevresel tutum ölçeği uygulanan analiz neticesinde faktör yükü 0,50'nin altında olan dört ifadenin ölçekten çıkarılması ile yedi ifadeye indirgenmiştir. Ölçekte toplam iki faktöre ulaşılmış ve bu faktörler Khare ve diğ. (2013) tarafından yapılan çalışmadaki gibi sosyal etki ve yeşil ürün satın alma olarak adlandırılmıştır. "Sosyal Etki" olarak adlandırılan birinci faktör üç ifadeden oluşmakta toplam varyansın \%33'ünü açıklamaktadır. Faktörü oluşturan major değişkenin "Arkadaşlarımla çoğunlukla çevre dostu ürünler satın almak için alışverişe çıkarız" $(, 875)$ ifadesi olduğu görülmektedir. Faktöre ilişkin ortalama değere bakıldığında $(1,64)$ Sosyal etki faktörünün öğrencilerin çevresel tutumları üzerinde düşük düzeyde etkili olduğu görülmektedir.

"Yeşil Satın Alma Davranışı" olarak adlandırılan ikinci faktör ise dört ifadeden oluşmakta ve toplam varyansın \%31.30'unu açıklamaktadır. Faktöre ilişkin değerlere bakıldığında "Çoğunlukla gelişmekte olan ülkelerdeki üreticilere yardım etmeyi ve sürdürülebilirliği teşvik etmeyi destekleyen markaların ürünlerini satın alııı" $(, 777)$ ifadesinin major değişken olduğu görülmektedir. 


\section{Tablo 3: Öğrencilerin Çevresel Tutumlarına İlişkin İfadelerin Faktör Analizi Sonuçları}

\begin{tabular}{|c|c|c|c|}
\hline 1.FAKTÖR Sosyal Etki & Eş Kök. & Yük & \\
\hline $\begin{array}{l}\text { Arkadaşlarımla çoğunlukla çevre dostu ürünler satın } \\
\text { almak için alışverişe çıkarız. }\end{array}$ & ,787 & 875 & \multirow{3}{*}{$\begin{array}{l}\text { Öz Değer: } \\
2,31 \\
\text { Varyans: } \\
\% 33,01 \\
\text { Ortalama: } \\
1,64\end{array}$} \\
\hline $\begin{array}{l}\text { Arkadaşlarım çoğunlukla bana çevre dostu ürünleri satın } \\
\text { almamı önerirler. }\end{array}$ & ,750 & 843 & \\
\hline $\begin{array}{l}\text { Arkadaşlarım yeşil ürünler hakkında sahip oldukları } \\
\text { birikimleri çoğunlukla benimle paylaşırlar. }\end{array}$ & ,632 & ,716 & \\
\hline \multicolumn{4}{|l|}{ 2.FAKTÖR Yeşil Satın Alma Davranışı } \\
\hline $\begin{array}{l}\text { Çoğunlukla gelişmekte olan ülkelerdeki üreticilere yardım } \\
\text { etmeyi ve sürdürülebilirliği teşvik etmeyi destekleyen } \\
\text { markaların ürünlerini satın alııım. }\end{array}$ & ,610 & 777 & \multirow{4}{*}{$\begin{array}{l}\text { Öz Değer: } \\
2,19 \\
\text { Varyans: } \\
\% 31,30 \\
\text { Ortalama: } \\
2,35\end{array}$} \\
\hline $\begin{array}{l}\text { Çoğunlukla geri dönüşümlü/geri dönüştürülebilir olarak } \\
\text { paketlenen ürünleri satın alırım. }\end{array}$ &, 583 & ,738 & \\
\hline $\begin{array}{l}\text { Çoğunlukla hiç kimyasal bileşen içermeyen ya da çok az } \\
\text { kimyasal bileşen içeren ürünleri satın alırım. }\end{array}$ &, 561 & ,708 & \\
\hline $\begin{array}{l}\text { Çoğunlukla çevresel yönden güvenli olarak etiketlenen } \\
\text { ürünleri satın alırım. }\end{array}$ & ,579 & 694 & \\
\hline
\end{tabular}

Varimax rotasyonlu temel bileşenler analizi. Açıklanan toplam varyans $\% 64,31$

Kaiser-Meyer-Olkin örneklem yeterliliği: \%83,3 Barlett küresellik testi: X2: 583, 655 s.d.: 21 p<0,001

Güvenilirlik: , 822 F-değeri 40,527 p-değeri,000

Öğrencilerin kişiler arası etkilenme eğilimi ile yeşil ürün satın alma davranışları arasındaki ilişkiyi belirlemeye yönelik korelasyon analizi (Pearson Korelasyon Katsayısı) yapılmış olup sonuçları Tablo 4'te gösterilmektedir. Korelasyon analizi sonuçlarına göre öğrencilerin kişiler arası etkilenme düzeyi ile yeşil ürün satın alma davranışı arasında ( $r=, 147 ; \quad p<.005)$ pozitif yönlü bir ilişki tespit edilmiştir. Başka bir değişle, tüketicilerin kişiler arası etkilenme düzeyi arttıkça, yeşil ürün satın alma davranışı da artacaktır. Bu sonuca göre, "H1: Kişilerarası etkilenme ile yeşil ürün satın alma davranışı arasında pozitif yönlü bir ilişki vardır" hipotezi kabul edilmiştir. Çalışmada ulaşılan bu sonuç Cheah ve Phau (2011) ve Khare ve diğ. (2013) tarafından gerçekleştirilen çalışmalarda ulaşılan sonuçlar ile benzerlik göstermektedir.

\section{Tablo 4: Öğrencilerin Kişilerarası Etkilenme ve Sosyal Etki ile Yeşil Ürün Satın} Alma Puanları Arasındaki İlişkiye Yönelik Korelasyon Analizi Sonuçları

\begin{tabular}{|l|c|c|c|c|c|c|}
\hline & $\begin{array}{l}\text { Kişilerarası } \\
\text { etkilenme gen. }\end{array}$ & Danışma & Beğenilme & Onaylama & Sosyal Etki & Yeşil Satın Alma \\
\hline $\begin{array}{l}\text { Kişilerarası } \\
\text { etkilenme genel }\end{array}$ & 1 & & & & & \\
\hline Danışma &, $727^{* *}$ & 1 & & & & \\
\hline Beğenilme &, $614^{\text {** }}$ &, $124^{*}$ & 1 & & & \\
\hline Onaylama &, $717^{\text {** }}$ &, $237^{\text {** }}$ &, $278^{\text {** }}$ & 1 & & \\
\hline Sosyal Etki &, $161^{* *}$ &, $219^{* *}$ &, 017 &, 066 & 1 & \\
\hline Yeşil Satın Alma &, $147^{*}$ &, $228^{* *}$ &,- 038 &, 072 &, $518^{* *}$ & 1 \\
\hline
\end{tabular}

${ }^{*} p<.005$ değerinde anlamlı.

${ }^{* *} p<.001$ değerinde anlamlı.

Kişiler arası etkilenme ölçeğinin alt boyutları ile yeşil ürün satın alma davranışı arasındaki ilişkiye bakıldığında, Danışma ile $(r=, 228 ; p<.001)$ yeşil ürün satın alma davranışı arasında pozitif yönlü bir ilişki tespit edilmiştir. Bu sonuca göre danışma düzeyi arttıkça öğrencilerin yeşil ürün satın alma davranışı da artmaktadır. Ancak beğenilme ve Onaylanma ile yeşil ürün satın alma davranışı arasında herhangi bir ilişki 
( $p>.001$ ) bulunamamıştır. Sosyal etki ile yeşil ürün satın alma davranışı arasındaki ilişkiye bakıldığında; iki değişken arasında pozitif yönlü bir iliş̧i $(r=, 518 ; p<.00)$ tespit edilmiştir. Bu sonuca göre "H2: Sosyal etki ile yeşil ürün satın alma davranışı arasında pozitif yönlü bir ilişki vardır" hipotezi kabul edilmiştir. Çalışmada ulaşılan bu sonuç Wahid ve diğ. (2011) ve Sharma (2014) tarafından gerçekleştirilen çalışmalarda ulaşılan sonuçlar ile benzerdir.

Sosyal etki ile yeşil ürün satın alma davranışı arasındaki ilişkiye ait basit doğrusal regresyon analizinin gösterildiği Tablo 5'e göre, değişkenler arasındaki doğrusal regresyon modelinin anlamlı olduğu tespit edilmiştir $(F=96,23 ; p<.001)$. Öğrencilerin yeşil ürün satın alma düzeyleri üzerinde sosyal etki \% 26 düzeyinde $\left(R^{2}=.26\right)$ etkilidir. Kalan \% $74^{\prime}$ lik kısım ise araştırmaya dâhil edilmeyen diğer değişkenlere bağlı olabilmektedir.

Tablo 5: Sosyal Etki ve Yeşil Satın Alma Davranışı Arasındaki İlişkiye Ait Basit Doğrusal Regresyon Analizi Sonuçları

\begin{tabular}{|c|c|c|c|c|c|c|c|}
\hline & B & Std.Hata & Beta & $\mathbf{T}$ & p & $\mathbf{F}$ & ANOVA \\
\hline Sabit & 1,600 & ,092 & \multirow[b]{2}{*}{, 518} & 17,46 & ,000 & \multirow{2}{*}{96,23} & \multirow[b]{2}{*}{, 000} \\
\hline Sosyal Etki & ,457 & ,047 & & 9,81 & ,000 & & \\
\hline
\end{tabular}

${ }^{*} \mathrm{p}<.001 ; R=.51 ; \quad R^{2}=.26 ; \quad$ Bağımlı Değişken: Yeşil Satın Alma

Kişilerarası etkilenme eğilimi ile yeşil ürün satın alma davranışı arasındaki ilişkiye ait basit doğrusal regresyon analizinin gösterildiği Tablo 6'ya göre, değişkenler arasındaki doğrusal regresyon modelinin anlamlı olduğu tespit edilmiştir $(F=5,74 ; p<$ .001). Öğrencilerin yeşil ürün satın alma düzeyleri üzerinde kişilerarası etkilenme \% 2 düzeyinde $\left(R^{2}=.02\right)$ etkilidir.

Tablo 6: Kişilerarası Etkilenme ve Yeşil Satın Alma Davranışı Arasındaki İlişkiye Ait Basit Doğrusal Regresyon Analizi Sonuçları

\begin{tabular}{|c|c|c|c|c|c|c|c|}
\hline & B & Std.Hata & Beta & $T$ & $p$ & $\mathbf{F}$ & ANOVA \\
\hline Sabit & 1,987 & ,16 & \multirow[b]{2}{*}{, 147 } & 12,2 & ,000 & \multirow{2}{*}{5,74} & \multirow[b]{2}{*}{,017 } \\
\hline Kişiler Arası Etk. & ,220 & ,09 & & 2,39 & ,017 & & \\
\hline
\end{tabular}

Yeşil ürün satın alma davranışının öğrencilerin demografik özelliklerine göre farklılık gösterip göstermediğini tespit etmek için yapılan ANOVA testi neticesinde, öğrencilerin yeşil ürün satın alma davranışının cinsiyete, anne ve babanın eğitim durumuna ve aylık ortalama hane gelirine göre istatistiksel olarak anlamlı farklılık göstermediği( $p>0,05)$ sonucuna ulaşılmıştır. Diğer bir değişle cinsiyet, anne ve babanın eğitim durumu ve aylık ortalama hane geliri gibi demografik değişkenler araştırmaya katılan öğrencilerin yeşil ürün satın alma davranışı üzerinde etkili değildir.

Tablo 7: Öğrencilerin Yeşil Satın Alma Düzeylerinin Demografik Özelliklerine İlişkin Farklıığı Gösteren ANOVA Testi Sonuçları

\begin{tabular}{|c|c|c|c|c|c|}
\hline Sınıf Düzeyi & $\mathbf{N}$ & Ort. & S.Sapma & F değeri & $\mathbf{P}$ \\
\hline Birinci Sınıf & 76 & 2,25 & ,095 & \multirow{4}{*}{4,353} & \multirow{4}{*}{,005 } \\
\hline İkinci Sınıf & 72 & 2,08 & 121 & & \\
\hline Üçüncü Sınıf & 29 & 2,50 & ,171 & & \\
\hline Dördüncü Sınıf & 87 & 2,59 &, 103 & & \\
\hline
\end{tabular}


Tablo 7'de görüldüğü üzere öğrencilerin yeşil ürün satın alma davranışı eğitim görülen sınıf düzeyine göre anlamlı farklılıklar $(p<0,05)$ göstermektedir. Tablo 7 'de en yüksek yeşil ürün satın alma davranış düzeyinin dördüncü sınıfta gerçekleştiği görülmektedir. Bu noktada çevre mühendisliği bölümünde görülen eğitiminin yeşil ürün satın alma davranışı üzerinde önemli bir etkiye sahip olduğu söylenebilir. Farkın hangi gruplar arasında anlamlı olduğunun tespit edilmesi için Tukey testi yapılmıştır. Bu analiz sonucunda ikinci sınıf ile dördüncü sınıf grupları arasındaki farklılıkların anlamlı olduğu tespit edilmiştir. Bu sonuca göre, Çevre Mühendisliği Bölümünde lisans eğitimi gören öğrencilerin sınıf düzeyi arttıkça çevre bilinçlerinin de arttığı ve bunun bir sonucu olarak çevre dostu yeşil ürünleri satın alma eğilimlerin olumlu yönde etkilendiği söylenilebilir.

\section{Sonuç ve Öneriler}

Çevre mühendisliği bölümde lisans eğitimi gören öğrencilerin yeşil ürün satın alma davranışları ile kişilerarası etkilenme eğilimi ve sosyal etki arasındaki ilişkinin incelendiği bu çalışmada, kişilerarası etkilenme eğilimi ve sosyal etki ile öğrencilerin yeşil ürün satın alma davranışları arasında pozitif yönlü bir ilişkinin olduğu tespit edilmiştir. Araştırmada ayrıca, demografik özelliklerin (cinsiyet, anne ve babanın eğitim durumu ve aylık ortalama hane geliri) bir tanesi hariç olmak üzere (sınıf düzeyi) öğrencilerin yeşil ürün satın alma davranışları üzerinde etki sahibi olmadığı belirlenmiştir. Araştırmada ulaşılan bu sonuca göre sınıf düzeyi arttıkça, öğrencilerin çevre bilinci de artmakta ve bunun sonucu olarak da yeşil ürün satın alma davranışları olumlu yönde etkilenmektedir. Bu kapsamda çevre mühendisliği bölümünde verilen eğitimin, öğrencilerin yeşil ürün satın alma davranışları üzerinde pozitif yönlü bir etkiye sahip olduğu söylenebilir.

Yeşil ürün satın alma davranışıyla ilgili alan yazını incelendiğinde sosyal ve kişilerarası etkinin çevre dostu tüketimin arttırılmasında ve tüketicilerin çevre dostu tüketim bilinci kazanmasında önemli bir yere sahip olduğu vurgulanmaktadır. Özellikle kişilerarası etki ve sosyal etkinin yeşil tüketim davranışı üzerindeki etkisini belirlemeye yönelik çalışmaların sayıca az olduğu görülmektedir. Oysa söz konusu bu iki etki tüketicilerin yeşil ürün taleplerini doğrudan veya dolaylı olarak yönlendirebilmektedir. Diğer yandan TUiK istatistiklerindeki verilerden hareketle eğitim, istihdam ve gelir olanakları bağlamında var olan toplumsal cinsiyet eşitsizliğinin kadınların yeşil ürün satın alma davranışını ne ölçüde etkilediği hatta belirlediği de araştırılabilir. Bundan sonraki çalışmalarda, toplumsal cinsiyet eşitsizliğinin yeşil tüketim davranışı üzerinde ne ölçüde etki sahibi olduğu ve eğer etkiliyse bu etkinin ne ölçüde olduğu ve ne şekilde yönetileceğini konu alan çalışmaların ilgili alana kazandırılması önerilmektedir.

\section{Kaynakça}

Arabacıoğlu, B. ve Tatıdil, R. (2009), 'Tüketicilerin Satın Alma Davranışında Çevre Bilincinin Etkileri' Ege Akademik Bakış, 9(2), ss. 435-461.

Autio, M. ve Heinonen, V. (2004), 'To Consume or Not To Consume?: Young People's Environmetalism in the Affluent Finnish Society' Journal of Youth Research, 12(2), ss. 137-153.

Atay, L. ve Dilek, S. E. (2013), 'Konaklama İşletmelerinde Yeşil Pazarlama Uygulamaları: İbis Otel Örneği' Süleyman Demirel Üniversitesi Íktisadi ve Idari Bilimler Fakültesi Dergisi, 18(1), ss. 203-219.

Ay, C. ve Ecevit, Z. (2005), 'Çevre Bilinçli Tüketiciler' Akdeniz Iktisadi ve Idari Bilimler Fakültesi Dergisi, 5(10), ss. 238-263. 
Ayyıldız, H. ve Genç, K. Y. (2008), 'Çevreye Duyarlı Pazarlama: Üniversite Öğrencilerinin Çevreye Duyarlı Pazarlama Uygulamaları ile İlgili Tutum ve Davranışları Üzerine Bir Araştırma' Atatürk Üniversitesi Sosyal Bilimler Enstitüsü Dergisi, 12(2), ss. 505-527.

Cheah, I. ve Phau, I. (2011), 'Attitudes Towards Environmentally Friendly Products' Marketing Intelligence \& Planning, 29(5), ss. 452-472.

Çabuk, S. ve Nakıboğlu, M. A. B. (2003), 'Çevreci Pazarlama ve Tüketicilerin Çevreci Tutumlarının Satın Alma Davranışlarına Etkileri ile İlgili Bir Uygulama' Çukurova Üniversitesi Sosyal Bilimler Enstitüsü Dergisi, 12(12), ss. 39-54.

Dagher, G. K ve Itanı, O. (2014), 'Factors Influencing Green Purchasing Behaviour: Emprical Evidence from the Labanese Consumers' Journal of Consumer Behaviour, 13(3), ss. 188-195.

Easterling, D., Kenworthy, A., Nemzoff, R. ve College, B. (1996), 'The Greening of Advertising: A Twenty-five Year Look at Environmental Advertising' Journal of Marketing Theory and Practice, 4(1), ss. 20-34.

Gilg, A., Barr, S. ve Ford, N. (2005), 'Green Consumption or Sustainable Lifestyle?: Identifying the Sustainable Consumer' Futures, 37(6), ss. 481-504.

Jain, S. K. ve Kaur, G. (2004), 'Green Marketing: An Attitudinal and Behavioural Analysis of Indian Consumers' Global Business Review, 5(2), ss. 187-205.

Jansson, J., Marell, A. ve Nordlund, A. (2010), 'Green Consumer Behavior: Determinants of Curtailment and Eco-Innovation Adoption' Journal of Consumer Marketing, 27(4), ss. 358-370.

Kalafatis, S. P., Pollard, M., East, R. ve Tsogas, M. H. (1999), 'Green Marketing and Ajzen's Theory of Planned Behaviour: A Cross-Market Examination' Journal of Consumer Marketing, 16(5), ss. 441-460.

Karaca, Ş. (2013), 'Tüketicilerin Yeşil Ürünlere İlişkin Tutumlarının İncelenmesine Yönelik Bir Araştırma' Ege Akademik Bakış, 13(1), ss. 99-111.

Khare, A., Mukerjee, S. ve Goyal, T. (2013), 'Social Influence and Green Marketing: An Exploratory Study on Indian Consumers' Journal of Customer Behaviour, 12(4), ss. 361-381.

Kuduz, N. (2011), Yeşil Pazarlama Faaliyetlerinin Tüketicilerin Satın Alma Davranışlarına Etkilerinin Belirlenmesine Yönelik Bir Araştırma, Yayımlanmamış Yüksek Lisans Tezi, Selçuk Üniversitesi, Sosyal Bilimler Enstitüsü, Konya.

Kükrer, Ö. (2012), 'Tüketicilerin Çevresel Sorumluluklarının Yeşil Reklamlara Yönelik Tutumlarına Etkisi: Eskişehir Örneği' Journal of Yasar University, 26(7), ss. 4505-4525.

Minton, A. P. ve Rose, R. L. (1997), 'The Effects of Environmental Concern on Behavior: An Exploratory Study' Journal of Business Research, 40(1), 37-48.

Mostafa, M. M. (2007), 'Gender Differences in Egyptian Consumers' Green Purchase Behaviour: The Effects of Environmental Knowledge, Concern and Attitude' International Journal of Consumer Studies, 31(3), ss. 220-229.

Paço, A., Alves, H., Shiel, C. ve Filho, W. L. (2013), 'Development of a Green Consumer Behaviour Model' International Journal of Consumer Studies, 37(4), ss. 414-421.

Paço, A. M. F., Raposo, M. L.B. ve Filho, W. L. (2009), 'Identifying the Green Consumer: A Segmentation Study' Journal of Targeting, Measurement and Analysis for Marketing, 17(1), ss. 17-25.

Park, S. Y. ve Sohn, S. H. (2012), 'Exploring the Normative Influences of Social Norms on Individual Environmental Behavior' Journal of Global Scholars of Marketing Science, 22(2), ss. 183-194.

Peattie, K. ve Crane, A. (2005), 'Green Marketing: Legend, Myth, Farce or Prophesy?' Qualiative Market Research: An International Journal, 8(4), ss. 357-370. 
Polonsky, M. J. (1994), 'An Introduction to Green Marketing' Electronic Green Journal, $1(2)$, ss. $1-10$.

Sharma, B. (2014), 'Consumers' Attitudes, Green Practices, Demographic and Social Influences, and Government Policies: An Emprical Investigation of their Relationships' Journal of New Business Ideas \& Trends, 12(2), ss. 22-36.

Straughan, D. R. ve Roberts, J. A. (1999), 'Environmental Segmentation Alternatives: A Look at Green Consumer Behavior in the New Millennium' Journal of Consumer Marketing, 16(6), ss. 558-575.

Türk, M. ve Gök, A. (2010), 'Yeşil Pazarlama Anlayışı Açısından Üretici İşletmelerin Sosyal Sorumluluğu' Elektronik Sosyal Bilimler Dergisi, 9(32), ss. 199-220.

Untaru, E. N., Epuran, G. ve Ispas, A. (2014), 'A Conceptual Framework of Consumers' Pro-Environmental Attitudes and Behaviıours in the Tourism Context' Economic Science, 56(2), ss. 85-94.

Wahid, N. A., Rahbar, E. ve Shyan, T. S. (2011), 'Factors Influencing the Green Purchase Behavior of Penang Environmental Voluntees' International Business Management, 5(1), ss. 38-49.

Xiao, C. ve McCright, A. M. (2015), 'Gender Differences in Environmental Concern: Revisiting the Institutional Trust Hypothesis in the USA' Environment and Behavior, 47(1), ss. 17-37.

TUiK (2017), 'Haber Bülteni', www.tuik.gov.tr/PreHaberBultenleri.do?id=21519 (11.04.2017).

TÜRK-İŞ (2017), 'Mart 2017 Açlık ve Yoksulluk Sınırı', www.turkis.org.tr/MART-2017ACLIK-ve-YOKSULLUK-SINIRI-d1446 (11.04.2017). 